\title{
Application of Natural Gas for Internal Combustion Engines
}

\author{
Rosli Abu Bakar ${ }^{1}$, K. Kadirgama ${ }^{1}$, M.M. Rahman ${ }^{1}$, K.V. Sharma ${ }^{1}$ and Semin ${ }^{2}$ \\ ${ }^{1}$ Faculty of Mechanical Engineering, University Malaysia Pahang, \\ 2Department of Marine Engineering, \\ Institut Teknologi Sepuluh Nopember, Surabaya, \\ ${ }^{1}$ Malaysia \\ ${ }^{2}$ Indonesia
}

\section{Introduction}

It is well known that the fossil-fuel reserves in the world are diminishing at an alarming rate and a lack of crude oil is expected at the early decades of this century (Aslam et al., 2006). Gasoline and diesel fuel becomes scarce and most expensive (Catania et al., 2004). Alternative fuel becomes more conventional fuel in the coming decades for internalcombustion engines. Nowadays, the alternative fuel has been growing due to concerns that the reserves of fossil fuel all over the area are limited. Furthermore, the world energy crisis made the fossil-fuel price increases.

Natural Gas (NG) has been found in various locations in oil and gas bearing sands strata located at different depths below the earth surface (Catania et al., 2004). NG is a gaseous form of NG was compressed. It has been recognized as one of the promising alternative fuels due to its significant benefits compared to gasoline fuel and diesel fuel. These include reduced fuel cost, cleaner exhaust gas emissions and higher octane number. Therefore, the numbers of engine vehicles powered by NG were growing rapidly (Poulton, 1994; Pischinger, 2003). NG is safer than gasoline in many respects (Cho and He, 2007; Ganesan, 1999; Kowalewicz, 1984). The ignition temperature of NG is higher than gasoline fuel and diesel fuel. Additionally, NG lighter than air and dissipate upward rapidly. Gasoline fuel and diesel fuel will pool on the ground, increasing the risk of fire. NG is nontoxic and will not contaminate groundwater if failed. Advanced NG engines undertake significant advantages over the conventional gasoline engine and diesel engine (Kato et al., 1999). NG is a commonly available type of fossil energy. However, the investigation of applying NG as an alternative fuel in engines will be a beneficial activity, because the liquid fossil fuels will be finished and will become scarce and expensive (Catania, 2004; Sera, 2003). NG has some advantages compared to gasoline and diesel from the environmental perspective. It is a cleaner fuel than either gasoline or diesel as far as emissions are concerned. NG is considered to be an environmentally clean alternative to those fuels (Cho and He, 2007; Kato et al., 1999; Shashikantha and Parikh, 1999; Wayne, 1998). Advantages of NG as a fuel its octane numbers are extraordinarily suitable for spark ignition (SI) engines. NG engine can be operated in high compression ratio (Ganesan, 1999). 


\section{Natural Gas engine}

\subsection{Natural Gas engine development trend}

There are four NG engine types, the traditional premixed charge spark ignition engine, the port injection lean burn engine, the dual-fuel/pilot injection engine, and the direct injection engine (Ouellette, 2000; Shashikantha and Parikh, 1999). Significant research has been done on these engines, the most promising of these, the injection engine requires further development in order to investigate the injection full potential. Shashikantha and Parikh (1999), studied a $17 \mathrm{~kW}$, stationary, direct injection diesel engine converted to operate as a gas engine using producer-gas and NG as the fuels on two different operational modes called SIPGE (Spark Ignition Producer Gas Engine) and DNGE ( Compressed NG Engine). Shashikantha and Parikh (1999) results of conversion to SIPGE (or DNGE) can be regarded as a success since comparable power and efficiency could be developed. NG operation of SIPGE yielded almost comparable power and higher efficiency, which establishes the fuel flexibility of the machine under spark ignition performance. The spark advance needed for producer-gas operation is much higher at $35^{\circ} \mathrm{BTDC}$ as compared to NG operation which is $22^{\circ}$ BTDC, with compression ratio being same, i.e., 11.5:1.

Kato et al. (1999) has developed a new engine Toyota Camry that uses NG as fuel by modifying the base 2.2-liter gasoline engine in the unmodified engine, torque and power for NG decrease compared to gasoline. The new engine has adopted a high compression ratio, intake valves with early closed timing, intake and advanced exhaust valves with increased lift and a small back pressure muffler, which thereby restores the loss of engine power. Fig. 1 shows a multi port injection or multi point injection system was chosen by Czerwinski et al. (2003), and the injectors and pressure regulator have been recently developed in order to significantly reduce exhaust emissions. At the same time, precise air-fuel (A/F) ratio control and special catalysts for NG exhaust gas have been utilized. The resulting NG engines output power has been restored to approach that of the gasoline base engine. Wang and Watson (2000) have developed of a NG engine with ultra-lean-burn low emissions potential, hydrogen-assisted jet ignition (HAJI) is used to achieve reliable combustion and low NOx emissions, whilst direct injection is used to improve thermal efficiency and reduce hydrocarbon (HC) emissions. It is found that port-inducted propane, port-inducted NG and directly injected NG all produce negligible levels of CO and NOx.

The vast majority of NG engines in use today is premixed charge spark ignition engines (Chiu, 2004). Spark ignited (SI) engines have significant advantages over diesel engines in terms of particulate and NOx emissions, there are some drawbacks with respect to performance. Premixed SI engines allow 30\% lower power output than equivalent size diesel engines due to knock limitations (Kato et al., 1999). In addition, SI engines receive high pumping losses, due to the need to throttle the intake air at part load conditions. These factors result in a 15 to $30 \%$ reduction in volumetric efficiency compared diesel engines (Brombacher, 1997). In diesel engine, Ouellette (2000) developed high pressure direct injection (HPDI) of NG in diesel engines, the result shown, that NG or methane are reduced by about $40 \%$ over diesel operation NOx. Peak torque loss $9 \%$ when running on NG compared to gasoline (Durell et al., 2000). Although peak power was not obtained on gas (due to the limitations of the injectors) there is also a predicted loss $9 \%$ on peak. 


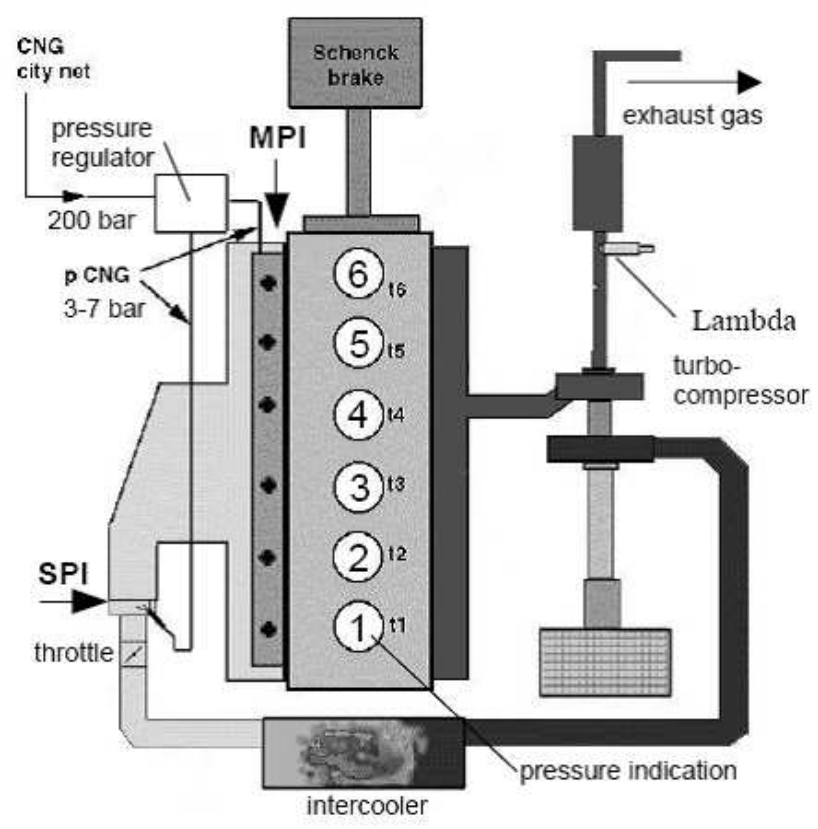

Fig. 1. Gas injection of NG engine.

The NG engine is best operated if such conditions as listed by Bakar et al. (2002) in Fig. 2. The principal operations are operated in high volumetric efficiency, turbulent flame speed, high compression ratio and proper air-fuel ratio. In operation in high volumetric efficiency and suitable of the air-fuel ratio is based on turbulent effect, injector type and lean burn operation. According to Bakar et al. (2002), injector is the important component in the best operation of NG engine. Another that, many researchers and institutions have contributed in improving the NG engine performance. In the area of increasing volumetric efficiency, Kubesh et al. (1995) developed an electronically controlled NG fueled engine with a turbocharged-aftercooled engine controlled by an electronic control system. Tilagone et al. (1996) found an increase up to $16 \%$ of thermal efficiency on a turbocharge spark ignition NG fuelled engine with multi point injection and optimized ignition timing with spark advance 200 higher running on stoichiometric A/F ratio.

In designing a turbulent effect in order to increase the flame speed combustion, Johansson and Olsson (1995) developed ten different geometries of the combustion chamber (CC). Their results showed a strong correlation between in cylinder turbulence and rate of heat release in the combustion process. However, the results also showed that geometries that gave the fastest combustion would gave the highest NOx values. In their further analysis, Johansson and Olsson (1995) developed six different CC to observe its effect on the combustion performance. The results showed different geometrical $\mathrm{CC}$, with the same compression ratio (12:1), have extremely different combustion performance. The Quartette type of CC gave the highest peak turbulence. A squish-generated charge motion combustion chamber had its effect to the burning rates. High levels of turbulent generated from the 


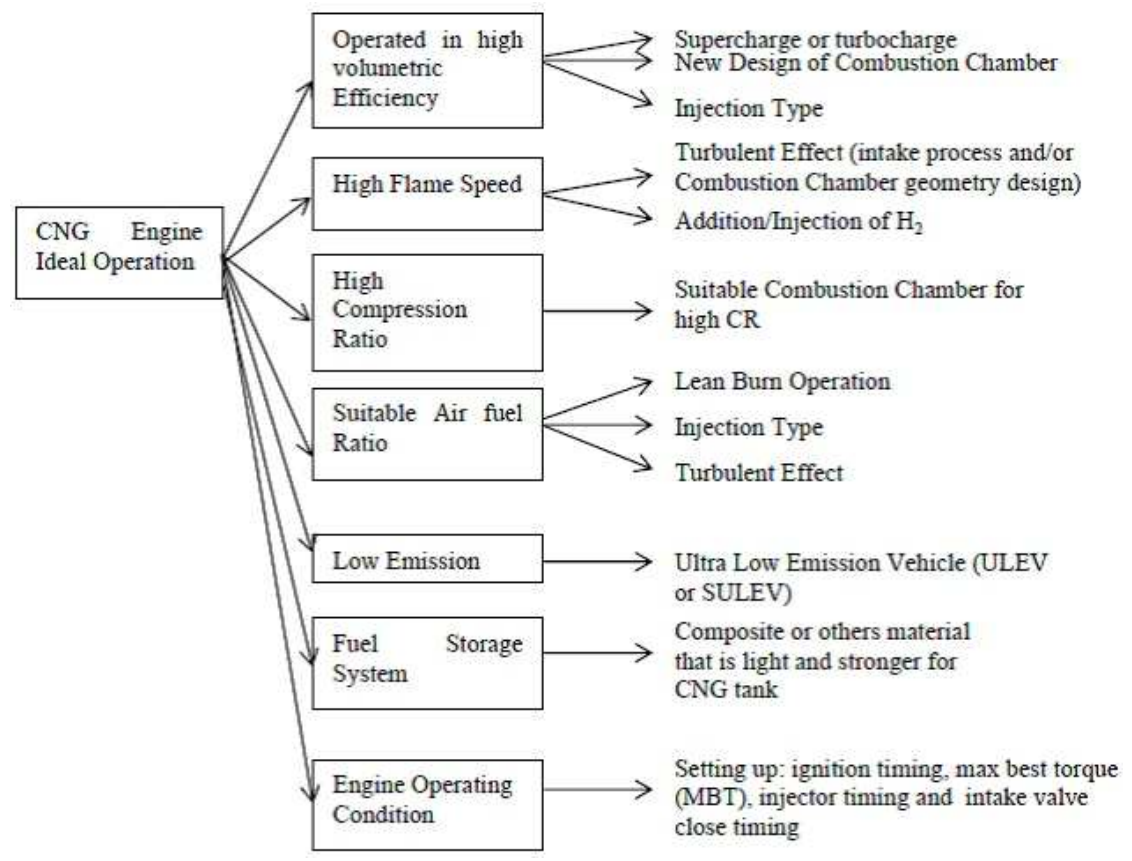

Fig. 2. The ideal NG engine operating conditions.

squish pretend to faster burning rates, which resulted in improvement of thermal efficiency. Evan et al. (1996) proved that the faster burning rates led to an average of $1.5 \%$ reduction in brake specific fuel consumption (BSFC) or $1.5 \%$ increase in power output under wide open throttle condition, as compare to the slowest burning cases. However the highest turbulence intensity combustion chamber also showed the highest emission.

In optimizing to the NG engine performance, Duan (1996) proposes the modification of setting up MBT, higher compression ratio and the use of gaseous fuel injection systems. Meanwhile, Ford introduces the NG Vehicle (NGV) truck by modifying fuel storage, fuel metering and emission control system. The injector timing, fuel control, spark advance, and exhaust gas recirculation (EGR) were also changed (Vermiglio, 1997). The simulations areas also conducted to increase the performance of NG engine. Oullette (1998) had simulated the combustion process and provides a better understanding of the injection and combustion process of the pilot-ignited directly-injected NG. The numerical simulation was expected to optimize the injection process by looking in especially at the geometry and the injection delay between two fuels. The model includes modifications for under expanded NG jets and includes a turbulent combustion model.

\subsection{Injection methods of Natural Gas engine}

There are four methods to inject the NG into the engine cylinder (Zastavniouk, 1997). First type is gas mixer / carburetor injection, second type is the single point injection, third type is multi point injection and fourth type is direct injection. The illustration of the four methods of NG injection is shown in Fig. 3. 


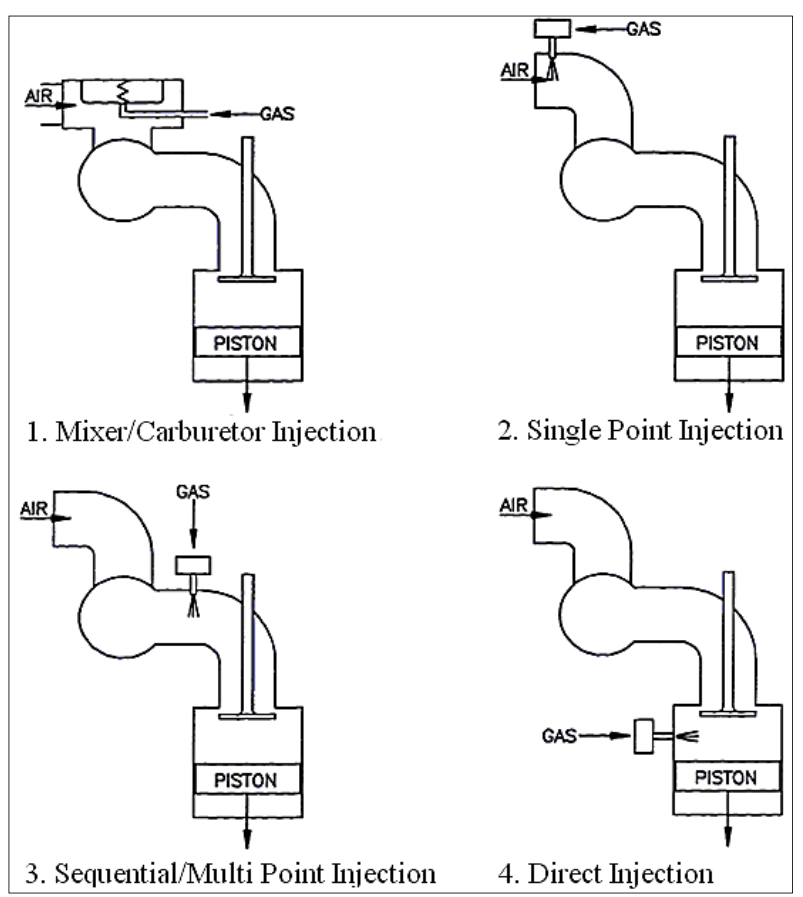

Fig. 3. Injection methods of NG engine.

The existing metering and mixing of the fuel may be accomplished using either a mechanical gaseous fuel mixer or carburetor, or an electronically controlled gaseous fuel metering system. This approach strives to achieve a homogeneous mixture of air and fuel before the air flow splits in the intake manifold. As discussed by Klimstra (1989), failure to obtain a homogenous mixture at this point can cause significant cylinder-to-cylinder variations in the air-fuel ratio. According to Zastavniouk (1997), Klimstra (1989) and Lino et al. (2008), this injection option can be increases emissions and the possibility of knock phenomena. Single point injection is use gaseous fuel injector to mix the gaseous fuel with the intake air in the manifold at one location for all cylinders of the engine. In this case, fuel is injected in a single location much like a gas mixer or carburetor. Single point electronic injection offers the advantage of more precise control of the amount of gaseous fuel entering the intake charge of the engine as well as the economy of using a minimum number of injectors (Zastavniouk, 1997). Multi point injection (MPI) is to inject the fuel into the each cylinder via intake port before intake valve (Czerwinski, 1999; 2003; Zastavniouk, 1997). This system uses one or more fuel injectors for each cylinder intake port of an engine and allows the designer to remove the fuel supply from the air supply area of the intake manifold. Direct injection is to inject the gaseous fuel directly into each combustion chamber of the engine.

In the MPI methods of NG, it is necessary to develop considerable turbulence during the compression stroke to obtain adequate air-fuel mixing. A high-turbulence, high swirl combustion chamber and high air-fuel mixing are useful for this type of injection to increase the engine performance. 


\subsection{Multi point injection system of Natural Gas}

According to Lino et al. (2008), the main elements of the NG injection system are a fuel tank storing high pressure gas, a pressure reducer, a common rail and electro-injectors. The MPI system of NG is shown in Fig. 4.

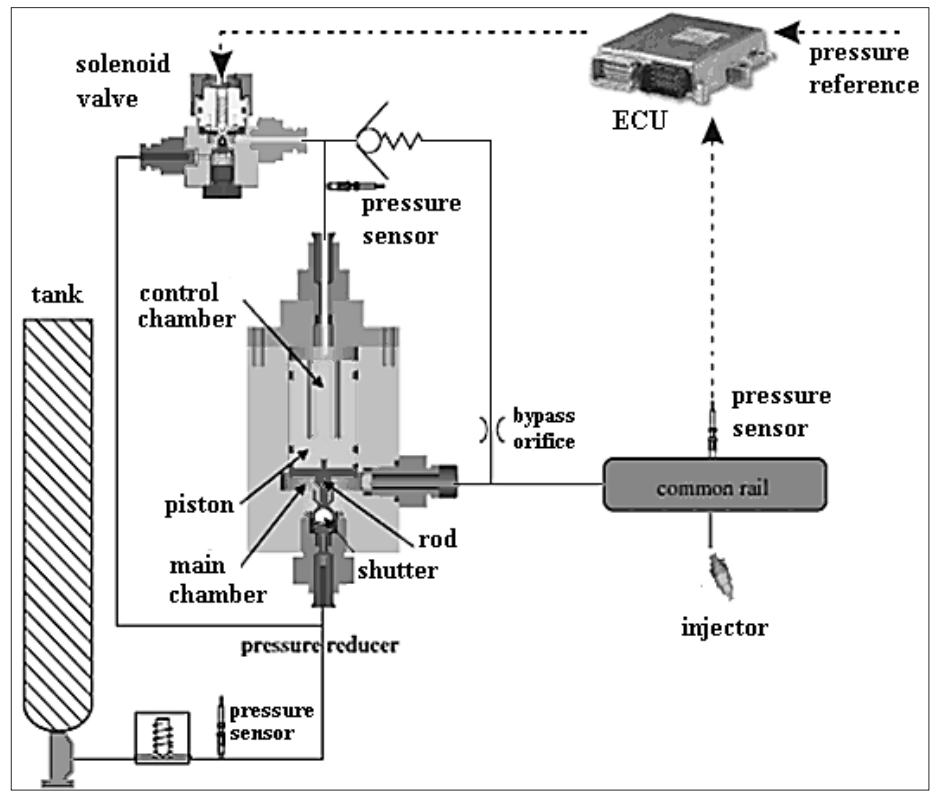

Fig. 4. Multi point injection system of NG engine.

The fuel coming from the tank supplies the pressure reducer before reaching the common rail and feeding the electronically controlled injectors. By supplying gas to the intake manifolds, injectors lead to the proper air/fuel mixture (Lino et al., 2008; Czerwinski et al., 1999; 2993). The large volume of the common rail helps in damping the oscillations due to the operation of both pressure controller and injectors. Namely, combining the electronic control of rail pressure with optimum design of the rail volume reduces the pressure oscillations inside the rail and leads to a more accurate fuel metering. The flow rate depends only on the rail pressure. Hence, the injected fuel quantity can be metered acting on rail pressure and injection timings are driven by the electronic control unit (ECU).

\subsection{Diesel engine convert to multi point injection Natural Gas engine}

In the diesel engines converted to run on NG, there are two main options discussed. The first is dual-fuel engine and the second is NG engine. Dual-fuel engine is referred to diesel engines operating on a mixture of NG and diesel fuel. NG has a low cetane rating and is not so suited to compression ignition, but if a pilot injection of diesel occurs within the gas/air mixture, standard ignition can be initiated. Between $50 \%$ and $75 \%$ of conventional diesel consumption can be replaced by gas when operating in this mode. The engine can also revert to $100 \%$ diesel operation. NG engines are optimized for the NG fuel. They can be 
derived from gasoline engines or may be designed for the purpose. According to Poulton (1994), until manufacturer original equipment (OE) engines are more readily available, however, the practice of converting diesel engines to spark ignition will continue, which involves the replacement of diesel fuelling equipment by a gas carburetor and the introduction of an ignition system and spark plugs. For compression ignition engines conversions to spark ignition, the pistons modified to reduce the actual compression ratio and a high-energy ignition system fitted (Czerwinski et al., 1999; 2003). The system is suitable for NG and is ideally suited to MPI system but can also be used for single point and low pressure in-cylinder injection. Gas production provides greater precision to the timing and quantity of fuel provided, and to be further developed and become increasingly used to provide better fuel emissions (Poulton, 1994).

The port injection NG produces negligible levels of CO, CO2 and NOx (Suga et al., 2000). In order to significantly reduce exhaust gas emissions, a port injection system was chosen by Czerwinski et al. (1999, 2003), Hollnagel et al. (1999, 2001) and Kawabata and Mori (2004), and the injectors and pressure regulator have been recently developed. In the same time, precise air-fuel (A/F) ratio control and specific catalysts NG exhaust gas has been utilized. By using it, NG engines output power near the gasoline base engine.

With the multi point injection, a high-speed gas stream is pulsed from the intake port through the open intake valve into the combustion chamber, where it causes effects of turbulence and charge stratification particularly at engine part load operations. The system is able to reduce the cyclic variations and to develop the border of lean operation of the engine. The flexibility of gas pulse timing offers the potential advantage of reduced emissions and fuel consumption. With three types of port injectors available on the market, Czerwinski et al. (2003) compared for stationary and transient engine operation. There are several advantages of port injection, e.g., better possibility to balance the air-fuel ratio of the cylinders, optimization of the gas injection timing and of the gas pressure for different operating conditions. The port injection has an injector for each cylinder, so the injectors can be placed in proximity to the cylinder's intake port. It also enables fuel to be delivered exactly as required for each individual cylinder (multi point injection) and enables more sophisticated technologies such as skip-firing to be used. Skip-firing is when only some of the cylinders are operating (the other cylinders are being skipped). This enables even more efficient use of the fuel at low loads, further lowering fuel consumption and unburned hydrocarbon (Czerwinski et al., 2003; Zastavniouk, 1997).

\subsection{Multi point injection gas injector}

In principle, the utilization of an optimal fuel-air mixture should provide the required power output with the lowest fuel consumption that is consistent with smooth and reliable operation (Zhao et al., 1995). Over past decades, MPI system has evolved into an electronic, pulse-width-modulated system that utilized multi point injectionly-timed separate injections into each intake port. According to Zhao et al. (1995), these transient sprays of 2.5 to $18.0 \mathrm{~ms}$ duration have a constant phase relative to the intake valve event, either for start on injection or end of injection, and provide significant advantages in engine transient response and hydrocarbon (HC) emissions. It is necessary to note, however, that the meteoric expansion in the use of such systems has generally out-paced the basic knowledge and understanding of the complex, transient fuel sprays that they produce. 
According to Shiga et al. (2002), improvement of NG injector nozzle holes geometries and understand of the processes in the engine combustion is a challenge because the compression-ignition combustion process is unsteady, heterogeneous, turbulent and three dimensional and exceedingly complex. In MPI NG engines, NG is injected by fuel nozzle injector via intake port into the combustion chamber and mixing with air must occur before ignition of the gas fuel. To improve the perfect of the mixing process of NG fuel and air in the combustion chamber is arranging of nozzle holes geometry, nozzle spray pressure, modified of the piston head, arranging of piston top clearance, letting the air intake in the formation of turbulent and changing the NG fuel angle of spray (Mbarawa et al., 2001). The NG fuel spraying nozzle is the amount of earning variation so that can be done by research experimentation and computational of engine power, cylinder pressure, specific fuel consumption and missions which also the variation of them. Czerwinski et al. $(1999,2003)$ has researched the multi point injection injection of NG offers several advantages to increase the NG engine performance. The injector multi holes geometries development is to provide optimum fuel air mixing of the engine that will promote a similar engine performance (Ren and Sayar, 2001). According to Czerwinski et al. (2003) NG MPI has advantages for the more efficiency. The power, fuel consumption and thermal efficiency of the engine are higher than carburetor and single point. In the port injection NG engine, every cylinder has least one injector and the fuel are injected from the intake manifold into the engine cylinder when the intake valve is opened.

\section{Development of multi point injection Natural Gas engine}

The development of MPI NG engine is using diesel engine as a baseline engine. The fuel in the diesel engine is changed to NG. The ignition system is compression ignition changed to spark ignition. The fuel injection system is from direct injection mechanical system changed to multi point injection system and managed by electronic control unit. The NG engine is using throttle to control the intake air. The development of NG engine is reducing the compression ratio by modified the piston surface. The fuel is injected from the intake manifold into the engine cylinder when the intake valve is opened. The engine performance investigation is based on experimental and computational.

\section{Multi point injection Natural Gas engine performance}

\subsection{Introduction}

This chapter is exploring the engine performance based on experimental and computational. The engine computational model is used in the preliminary design to simulate the compression ratio effect of multi point port injection NG engine converted from diesel engine. The compression ratio has given the significant impact on engine power performance. In the engine computational model, if the compression ratio of the diesel engine convert to multi point port injection NG engine is designed in 12.5:1, 13.5:1, 14.5:1, 15.5:1, 16.5:1, 17.5:1, 18.5:1, 19.5:1 and 20.28:1, the brake power of the engine has been reduced $42.2 \%, 41.71 \%, 41.37 \%, 41.51 \%, 41.43 \%, 41.48 \%, 41.78 \%, 42.0 \%$ and $42.23 \%$. Based on this brake power performance reduction effect from the compression ratio, the compression ratio with lower reduce brake power will be used in the engine conversion. The compression ratio 14.5:1 will be used in the development of multi point port injection NG engine. The engine conversion data are shown in Table 1. 


\begin{tabular}{|l|c|c|}
\hline Engine Parameter & Diesel Engine & NG Engine \\
\hline Bore $(\mathrm{mm})$ & 86.0 & 86.0 \\
Stroke $(\mathrm{mm})$ & 70.0 & 70.0 \\
Displacement $(\mathrm{cc})$ & 407.0 & 407.0 \\
Compression ratio & $20.28: 1$ & $14.5: 1$ \\
Ignition system & Compression Ignition & Spark Ignition \\
Engine Management & Mechanical Control & Electronic Control \\
Fuel system & Direct Injection & Multi point Port Injection \\
Fuel & Diesel & Natural Gas \\
\hline
\end{tabular}

Table 1. Specification the engine conversion.

\subsection{Cylinder pressure of multi point injection Natural Gas engine}

The results of cylinder pressure performance of direct injection diesel engine, compression ratio modified direct injection diesel engine and multi point port injection NG engine are shown in Fig. 5.

The results investigation of engine cylinder pressure is based on crank angle degree. The negative 180 to 0 crank angle degree is the engine compression stroke and the 0 to $180 \mathrm{crank}$ angle degree is the engine power stroke for original diesel engine (ODE), compression ratio modified diesel engine (14.5CR DE) and MPI NG engine (NGE).

The engine cylinder pressure profile investigation results are shown in Fig. 5 are shown that the cylinder pressure is increasing in compression stroke to combustion ignition in crank angle negative180 degree bottom dead center (BDC) until around in crank angle 0 degree top dead center force (TDCF). In the compression stroke, the air-fuel volume is compressed from BDC to TDC. The simulation and experiment results are not similar. The simulation results are higher than the experimental results. The deviation is in average $2 \%$ for NG engine (NGE) and original diesel engine (ODE). The compression ratio of original direct injection diesel engine is 20.28:1, the compression ratio of modified direct injection diesel engine is $14.5: 1$ and the compression ratio of port injection NG engine is $14.5: 1$. From 1500 to $4000 \mathrm{rpm}$ engine speed are shown that the original direct injection diesel engine cylinder pressure is higher than the modified direct injection diesel engine and multi point port injection NG engine. The highest of cylinder pressure is around in crank angle 0 degree (TDCF). From the cylinder pressure performance can be predicted that the product of engine power from the air-fuel combustion of original direct injection diesel engine is higher than modified direct injection diesel engine and the multi point port injection NG engine. The original direct injection diesel engine cylinder pressure is higher than modified direct injection diesel engine and multi point port injection NG engine because the compression ratio of original diesel engine is higher.

The highest of maximum cylinder pressure in the combustion process both of diesel engines and for multi point port injection NG engine are shown in Fig. 5a. In the original diesel engine, the maximum cylinder pressure is 84.0 bar declared in $1500 \mathrm{rpm}$ engine speed. In the modified diesel engine, the maximum cylinder pressure is 61.1 bar declared in $1500 \mathrm{rpm}$ engine speed. In the multi point port injection NG engine, the maximum cylinder pressure is 76.23 bar and declared in $1500 \mathrm{rpm}$ engine speed. In this operating condition, both of diesel engines and NG engine combustion process are most excellent than the other condition. In 
the diesel engine, the $1500 \mathrm{rpm}$ engine speed condition is not higher and not lower for the combustion of diesel fuel. Burned diesel fuel rate in $1500 \mathrm{rpm}$ is most excellent to product the higher pressure and power. In the multi point port injection NG engine, the $1500 \mathrm{rpm}$ engine speed condition is not higher and not lower for the combustion of NG engine. Burned NG fuel rate in $1500 \mathrm{rpm}$ is most excellent and product the higher pressure and torque of the engine. The trend of the maximum cylinder pressure for original direct injection diesel engine, modified direct injection diesel engine and port injection NG engine are decrease if the engine speed is increased.

Fig. $5 \mathrm{f}$ shows the lowest of maximum cylinder pressure of direct injection diesel engine, modified direct injection diesel engine and MPI NG engine. The lowest maximum cylinder pressure in combustion process of original direct injection diesel engine, modified direct injection diesel engine and port injection NG engine are shown in $4000 \mathrm{rpm}$ engine speed and the nominal is 72.82 bar for original diesel engine, 52.29 bar for modified diesel engine and 25.00 bar for port injection NG engine. In this case the combustion of diesel engines and NG engine are in lately so the combustion process is not excellent and unburned fuel is highest, this phenomenon can be decreasing the engine cylinder pressure performance. The port injection NG engine maximum cylinder pressure is lowest because the natural gas fuel is lower in density, hydrocarbon and energy than the diesel fuel. So, the cylinder pressure in the same compression ratio, the NG engine is lower than modified diesel engine if the engines are operated in high speed. The lowest cylinder pressure of original diesel engine is higher than modified diesel engine because the compression ratio of original diesel engine is higher than modified diesel engine.

The maximum cylinder pressure effect of the diesel engine converted to multi point port injection NG engine in the similar or higher compression ratio and in variation engine speed is shown in Fig. 5. In the $1500 \mathrm{rpm}$ engine speed, the conversion of diesel engine to NG engine is increase the maximum cylinder pressure $8.97 \%$. In the $2000 \mathrm{rpm}$ engine speed, the conversion of diesel engine to NG engine is decrease the maximum cylinder pressure $1.70 \%$.

In the $2500 \mathrm{rpm}$ engine speed, the conversion of diesel engine to NG engine is decrease the maximum cylinder pressure $13.53 \%$. In the $3000 \mathrm{rpm}$ engine speed, the conversion of diesel engine to NG engine is decrease the maximum cylinder pressure $39.12 \%$. In the $3500 \mathrm{rpm}$ engine speed, the conversion of diesel engine to NG engine is decrease the maximum cylinder pressure $51.40 \%$. At the $4000 \mathrm{rpm}$, the conversion of diesel engine to NG engine is decrease maximum cylinder pressure $58.56 \%$.

The maximum cylinder pressure for NG engine is lower than the original diesel engine. It caused the compression ratio of NG engine is lower than the original diesel engine and the combustion energy output of diesel fuel is produces highest power than the natural gas fuel. Another that, the density of natural gas fuel is lower than the diesel fuel. So, in the same volume, the diesel fuel is has higher pressure than the gas fuel. In this engine conversion, the NG engine better to operate at low speed. In the low speed the maximum cylinder pressure increasing is higher dramatically than at the medium and high speed. For all of engine speed, the conversion of modified diesel engine to NG engine is increase the cylinder pressure in low speed, but in the high speed the engine conversion can be decreasing the cylinder pressure. In the high speed NG engine, the fuel energy is reduced and the combustion is not completely, but in the low speed the combustion of NG engine is completely because the combustion ignition is assisted by spark plug system and the 


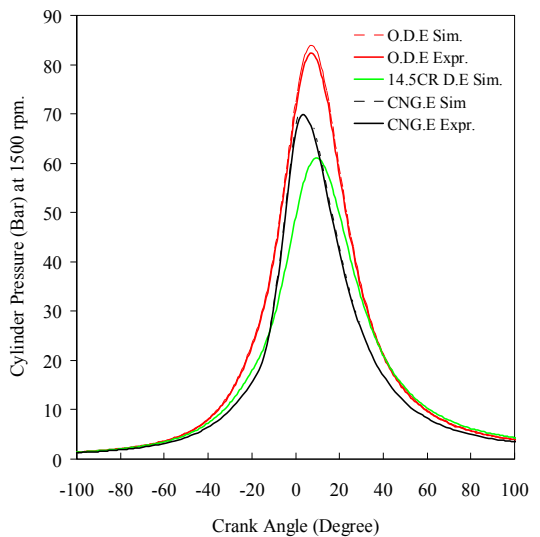

a) Cylinder pressure in $1500 \mathrm{rpm}$

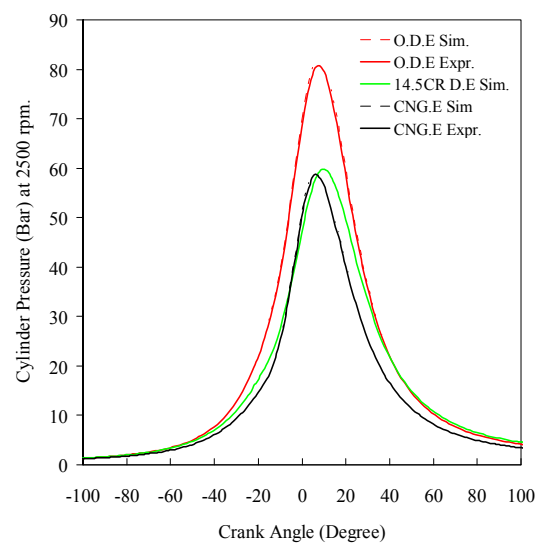

c) Cylinder pressure in $2500 \mathrm{rpm}$

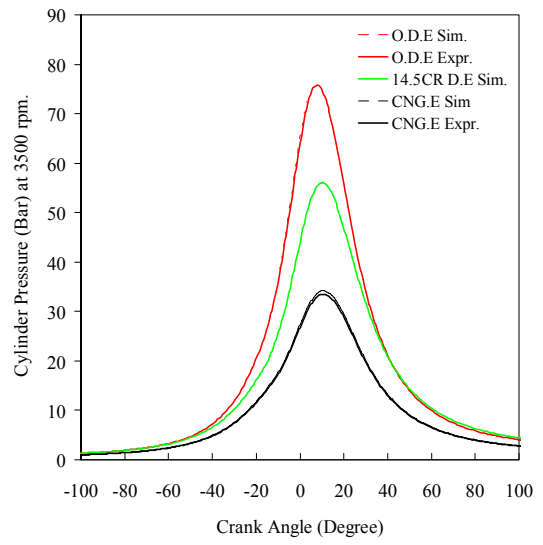

e) Cylinder pressure in $3500 \mathrm{rpm}$

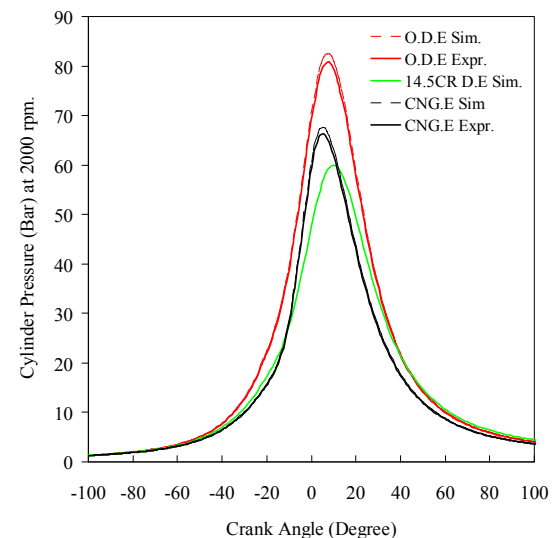

b) Cylinder pressure in $2000 \mathrm{rpm}$

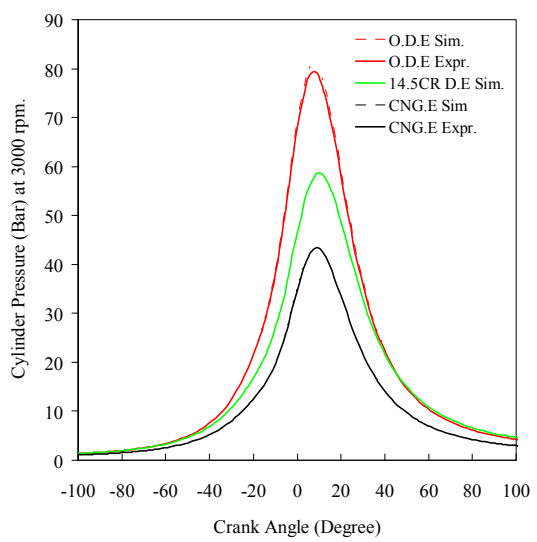

d) Cylinder pressure in $3000 \mathrm{rpm}$

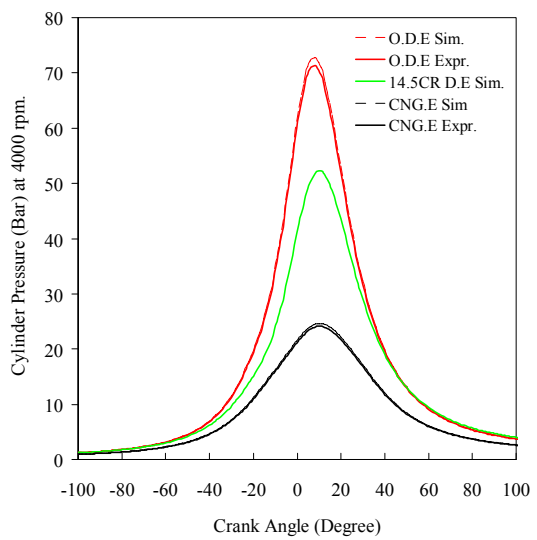

f) Cylinder pressure in $4000 \mathrm{rpm}$

Fig. 5. Cylinder pressure of diesel engine convert to MPI NG engine. 
ignition point of natural gas fuel is higher than the diesel fuel, so it can be producing the higher engine cylinder pressure.

\subsection{Cylinder temperature of multi point injection Natural Gas engine}

The investigation results of the engine cylinder temperature characteristics of original direct injection diesel engine (O.D.E), modified direct injection diesel engine (14.5CR D.E) and multi point port injection NG engine (NG.E) are shown in Fig. 6. In these figures, negative 180 to 0 degree is compression stroke and the 0 to 180 degree is power stroke for diesel engines and NG engine. The average deviation result of simulation and experiment is $2 \%$ for ODE and NGE.

In the low speed, the engine cylinder temperature of NG engine is higher than original diesel engine and modified diesel engine as shown in Fig. 6. In the high speed, the engine cylinder temperature fro both of diesel engines are higher than NG engine as shown from Fig. 6a to Fig. 6f.

The results are shown that increasing engine speed of diesel engine can be increase the maximum temperature in-cylinder engine. Unfortunately, the increasing engine speed of NG engine will be decrease maximum temperature in-cylinder engine. The decreasing engine speed of diesel engines will be decrease maximum temperature in-cylinder engine. Decreasing engine speed of NG engine will be increase maximum temperature in-cylinder engine. In this investigation results are shown that the highest maximum in-cylinder temperature in combustion process is not declared in the highest engine speed. In the both of diesel engines, the highest maximum temperature in-cylinder is declared in $3500 \mathrm{rpm}$ engine speed, because in this case the combustion is most excellent than the other condition and unburned fuel is lowest, so the temperature product from the combustion is the highest. In the both of diesel engines, the lowest maximum temperature in combustion process is in 1500 rpm engine speed.

In this engine speed, the combustion process is not excellent and unburned fuel is highest than the other condition for compression stroke of compression ignition diesel engines. In the NG engine, the highest maximum temperature in-cylinder is declared in $1500 \mathrm{rpm}$ engine speed, because in this case the combustion is most excellent than the other condition and unburned fuel is lowest, so the temperature product from the combustion is the highest. In the NG engine, the lowest maximum temperature in combustion process is in $4000 \mathrm{rpm}$ engine speed. After $1500 \mathrm{rpm}$, the increasing engine speed, the combustion process is not excellent, the gas fuel density is lower, the air-fuel volume is lower and unburned fuel is highest than the other condition for compression stroke of natural gas spark assisted combustion engine. In the low speed, the engine cylinder temperature of NG engine is higher than original diesel engine and modified diesel engine as shown in Fig. 6a. In the high speed, the engine cylinder temperature fro both of diesel engines are higher than NG engine as shown from Fig. 6a to Fig. 6f.

The results are shown that increasing engine speed of diesel engine can be increase the maximum temperature in-cylinder engine. Unfortunately, the increasing engine speed of NG engine will be decrease maximum temperature in-cylinder engine. The decreasing engine speed of diesel engines will be decrease maximum temperature in-cylinder engine. Decreasing engine speed of NG engine will be increase maximum temperature in-cylinder 


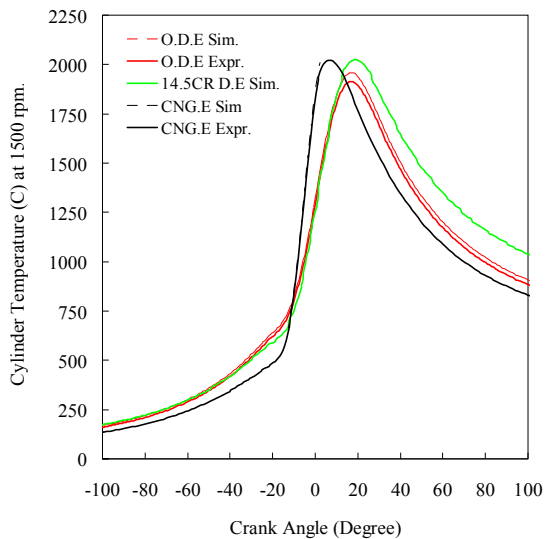

a) Cylinder temperature in $1500 \mathrm{rpm}$

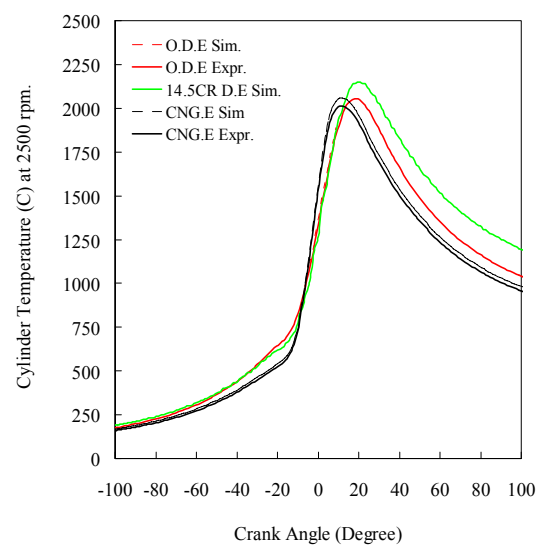

c) Cylinder temperature in $2500 \mathrm{rpm}$

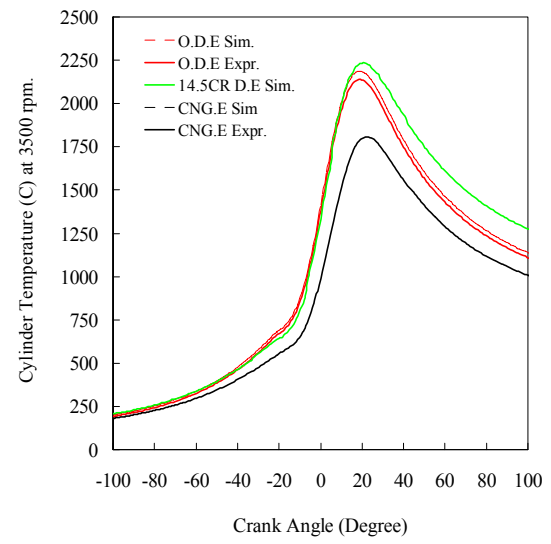

e) Cylinder temperature in $3500 \mathrm{rpm}$

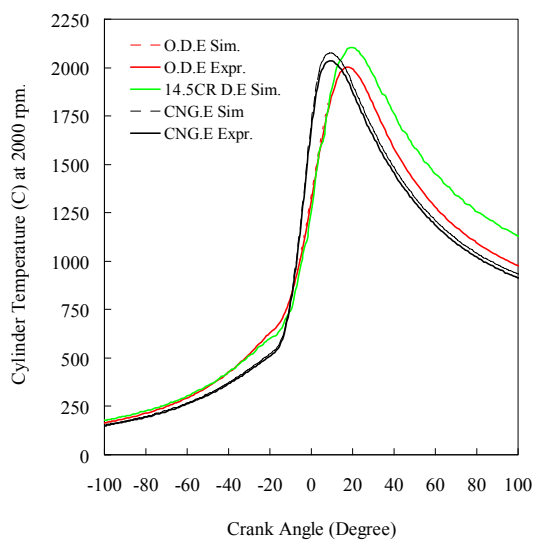

b) Cylinder temperature in $2000 \mathrm{rpm}$

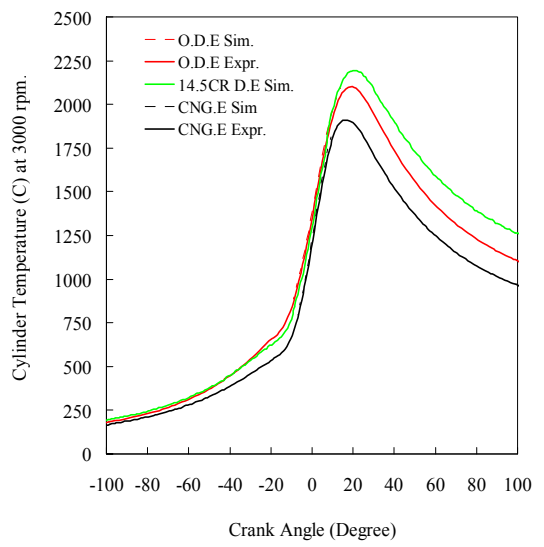

d) Cylinder temperature in $3000 \mathrm{rpm}$

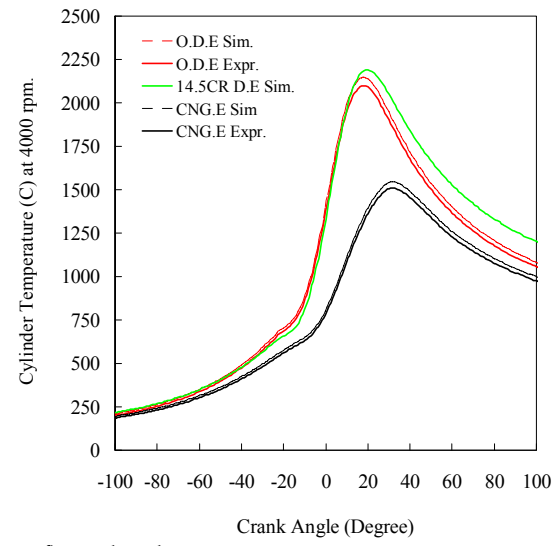

f) Cylinder temperature in $4000 \mathrm{rpm}$

Fig. 6. Cylinder temperature of diesel engine convert to MPI NG engine. 
engine. In this investigation results are shown that the highest maximum in-cylinder temperature in combustion process is not declared in the highest engine speed. In the both of diesel engines, the highest maximum temperature in-cylinder is declared in $3500 \mathrm{rpm}$ engine speed, because in this case the combustion is most excellent than the other condition and unburned fuel is lowest, so the temperature product from the combustion is the highest. In the both of diesel engines, the lowest maximum temperature in combustion process is in $1500 \mathrm{rpm}$ engine speed. In this engine speed, the combustion process is not excellent and unburned fuel is highest than the other condition for compression stroke of compression ignition diesel engines. In the NG engine, the highest maximum temperature in-cylinder is declared in $1500 \mathrm{rpm}$ engine speed, because in this case the combustion is most excellent than the other condition and unburned fuel is lowest, so the temperature product from the combustion is the highest. In the NG engine, the lowest maximum temperature in combustion process is in $4000 \mathrm{rpm}$ engine speed. After $1500 \mathrm{rpm}$, the increasing engine speed, the combustion process is not excellent, the gas fuel density is lower, the air-fuel volume is lower and unburned fuel is highest than the other condition for compression stroke of natural gas spark assisted combustion engine.

The effect of diesel engine converted to multi point port injection NG engine on the maximum engine cylinder temperature is shown in Fig. 6a - Fig. 6f. In the $1500 \mathrm{rpm}$, conversion of modified diesel engine to NG engine has been increase the maximum engine cylinder temperature $5.29 \%$ and $1.94 \%$. In the 2000 to $4000 \mathrm{rpm}$ engine speed, conversion of engine has been decrease the maximum engine cylinder temperature $2.18 \%, 5.88 \%, 15.34 \%$, $23.36 \%$ and $28.15 \%$.

\subsection{Torque performance of multi point injection Natural Gas engine}

The engine torque performance investigation results of diesel engine convert to multi point port injection NG engine are shown in Fig. 7a - Fig. 7c.

The indicated torque results are shown in Fig. 7a. The simulation and experimental investigation results are not similar in 0.1 to $1.0 \%$. The simulation results are higher than the experimental results, it caused by the not excellently setting and reading data experiment and the assumption in simulation with not have losses. The indicated torque represents the thermodynamic work transferred from the gas to the piston converted via geometry to a torque applied to the crankshaft. In the original diesel engine, the highest indicated torque is $24.3453 \mathrm{Nm}$ and declared at $3000 \mathrm{rpm}$ engine speed. In the modified diesel engine, the highest indicated torque is $23.76 \mathrm{Nm}$ and declared at $3000 \mathrm{rpm}$ engine speed. The diesel engines indicated torque performance profile shows that from the minimum engine speed at $1500 \mathrm{rpm}$ to $3000 \mathrm{rpm}$ as the point of the highest indicated torque, the indicated torque performance is increase if the engine speed is increased until $3000 \mathrm{rpm}$ engine speed. After $3000 \mathrm{rpm}$ engine speed, the increasing engine speed can be decrease the indicated torque. In the port injection NG engine, the highest indicated torque is $20.4798 \mathrm{Nm}$ and declared at $2000 \mathrm{rpm}$ engine speed. After $2000 \mathrm{rpm}$ engine speed, the increasing engine speed can be decrease the indicated torque. Based on Fig. 7a, the conversion diesel engine to NG engine can reduce the engine torque performance. The maximum indicated torque of diesel engine convert to NG engine is reduced $15.88 \%$. The increasing engine speed can be increase the deviation percentage of the indicated torque of diesel engines compared to NG engine. On 1500 to $4000 \mathrm{rpm}$, the NG engine has reduce indicated torque of $11.08 \%, 13.43 \%, 23.51 \%$, 

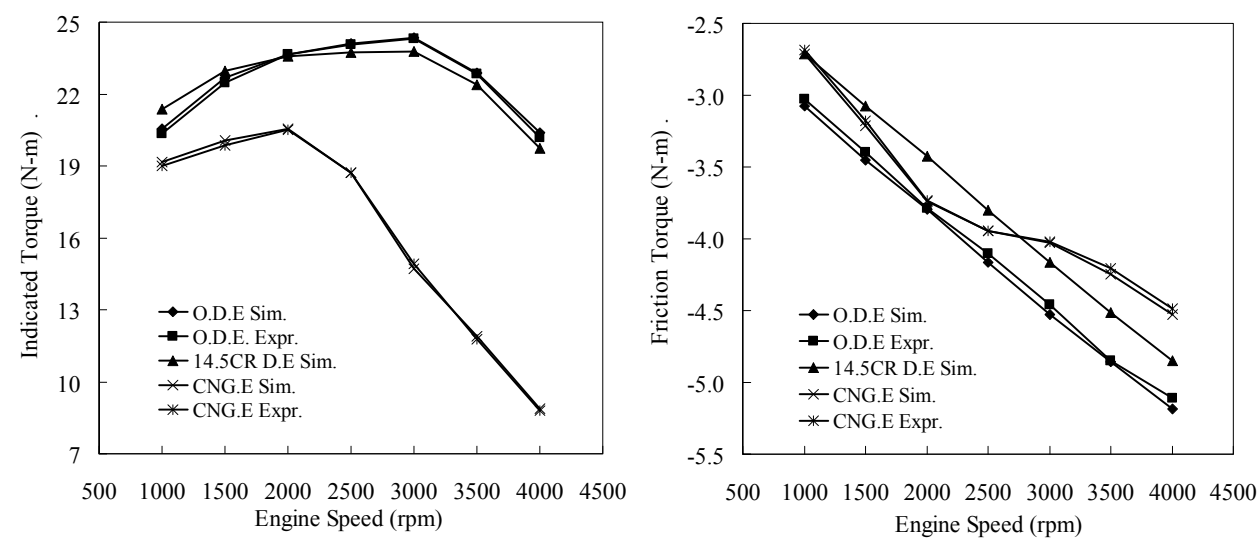

a) Indicated torque of NG engine compared to diesel engines

b) Friction torque of NG engine compared to diesel engines

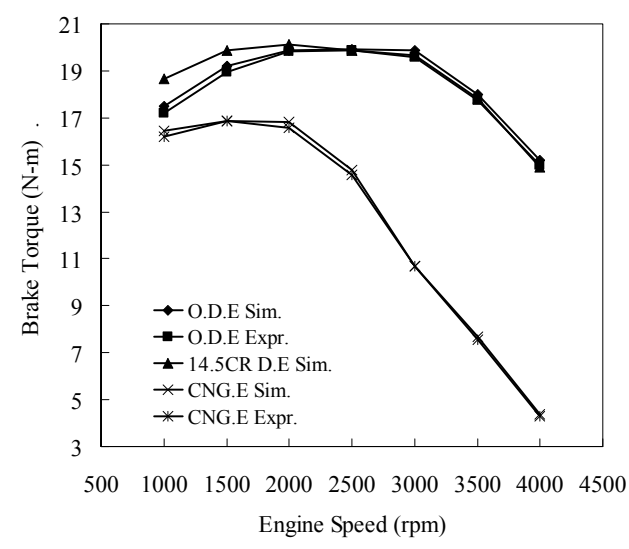

c) Brake torque of NG engine compared

Fig. 7. Torque performance of diesel engine convert to MPI NG engine.

$41.29 \%, 50.34 \%$ and $56.54 \%$. It meant that the thermodynamics energy were resulted from the diesel fuel combustion is higher than the NG fuel. It caused by the hydrocarbon chain, density and energy of diesel fuel of diesel engine is higher than the gas fuel of NG engine were ignited using spark assistant.

The friction torque result is sown in Fig. $7 \mathrm{~b}$. The simulation results are higher than the experimental results, it caused by the not excellently setting and reading data experiment and the assumption in simulation with not have losses. The highest friction torque in the original diesel engine is negative $5.18 \mathrm{Nm}$ and modified diesel engine is negative $4.85 \mathrm{Nm}$ declared at $4000 \mathrm{rpm}$ engine speed. In the diesel engines, the friction torque is increase if the engine speed is increased. In the NG engine, the highest friction torque is negative $4.44 \mathrm{Nm}$ 
and declared at $4000 \mathrm{rpm}$ engine speed. In the NG engine and diesel engine, the friction torque is increase if the engine speed is increased. The conversion diesel engine to NG engine can increase the friction torque. The increasing engine speed can be increase the friction torque. Based on engine speed increasing, the percentage friction torque of NG engine is higher than the diesel engine in every engine speed. In $1500 \mathrm{rpm}$, the friction torque of NG engine is $15.02 \%$ and diesel engine is $15.21 \%$ from the indicated torque, where in this engine speed the reducing torque of diesel engine is higher than NG engine. In 2000 $\mathrm{rpm}$, the friction torque of NG engine is $17.45 \%$ and diesel engine is $16.03 \%$ from the indicated torque, where in this engine speed the reducing torque of diesel engine is lower than NG engine. In $2500 \mathrm{rpm}$, the friction torque of NG engine is $20.57 \%$ and diesel engine is $17.29 \%$ from the indicated torque, where in this engine speed the reducing torque of NG engine is higher than diesel engine. In $3000 \mathrm{rpm}$, the friction torque of NG engine is $27.22 \%$ and diesel engine is $18.6 \%$ from the indicated torque, where in this engine speed the reducing torque of NG engine is exactly continue higher than diesel engine and the percentage deviation is increase. In $3500 \mathrm{rpm}$, the friction torque of NG engine is $36.4 \%$ and diesel engine is $21.23 \%$ from the indicated torque, where in this engine speed the reducing torque of NG engine is exactly continue higher than diesel engine and the percentage deviation is increase. In $4000 \mathrm{rpm}$, the friction torque of NG engine is $50.17 \%$ and diesel engine is $25.44 \%$ from the indicated torque, where in this engine speed the reducing torque of NG engine is exactly continue higher and the percentage deviation is increase. If the engine is running in higher than $1500 \mathrm{rpm}$ engine speed, the NG engine friction torque is higher than diesel engine. In these cases, increasing engine speed will be increase the friction torque both of the engines, but the NG engine give the higher friction torque. It meant that the conversion of diesel engine to NG engine can be increase the friction torque of engine. It is caused by the natural gas as a fuel is less lubrication compared to diesel fuel as a liquid fuel and has the lubrication.

Brake torque of original diesel engine, modified diesel engine and NG engine are shown in Fig. 7c. The simulation results are higher than the experimental results, it caused by the not excellently setting and reading data experiment and the assumption in simulation with not have losses. Brake torque represents the torque available at the flywheel, after accounting for all friction and attachment losses as well as the acceleration of the crank train inertia. In the original diesel engine, the highest brake torque is $19.89 \mathrm{Nm}$ declared at $2500 \mathrm{rpm}$ engine speed. In the modified diesel engine, the highest brake torque is $20.12 \mathrm{Nm}$ declared at 2000 rpm engine speed. In the diesel engine, the brake torque performance profile shows that from the low engine speed to medium engine speed, the brake torque performance is increase if the engine speed is increased. After $2500 \mathrm{rpm}$ engine speed, the increasing engine speed can be decrease the brake torque. In the NG engine, the highest brake torque is 17.14 $\mathrm{Nm}$ and declared at $1500 \mathrm{rpm}$ engine speed. After $1500 \mathrm{rpm}$ engine speed, the increasing engine speed can be decrease the brake torque. The conversion of diesel engine to NG engine can reduce the engine brake torque. The maximum brake torque of modified diesel engine convert to NG engine is reduced $16.18 \%$. The increasing engine speed can be increase the deviation point or percentage of the brake torque of diesel engine compared to NG engine. If the engines are run on 1500 to $4000 \mathrm{rpm}$, the conversion diesel engine to NG engine reduced brake torque $15.14 \%, 16.47 \%, 25.67 \%, 45.68 \%, 57.04 \%$ and $70.68 \%$. Lower brake torque NG engine is caused by lower energy of and higher friction NG fuel. 


\subsection{Power performance of multi point injection Natural Gas engine}

Indicated power performance of original diesel engine, modified diesel engine and port injection NG engine are shown in Fig. 8a. Indicated power represents the thermodynamic power transferred from the gas to engine. In the NG engine, the highest indicated power is $4.9 \mathrm{~kW}$ declared on $2500 \mathrm{rpm}$ engine speed. From the minimum engine speed to $2500 \mathrm{rpm}$ engine speed, the increasing engine speed can be increase the indicated power performance. After $2500 \mathrm{rpm}$ to maximum engine speed, the increasing engine speed can be decrease the indicated power performance. The simulation and experimental investigation results are not similar in 0.05 to $0.5 \%$, it caused by the not excellently setting and reading data experiment and the assumed in simulation with not have losses. In the original diesel engine and modified diesel engine, the highest indicated power is $8.54 \mathrm{~kW}$ and $8.27 \mathrm{~kW}$ declared on $4000 \mathrm{rpm}$ engine speed. The maximum indicated power of modified direct injection diesel engine convert to port injection NG engine is reduced $40.7 \%$. The increasing engine speed can be increase the deviation point or percentage deviation of the indicated power of NG engine compared to diesel engine. From the 1500 to $4000 \mathrm{rpm}$, the conversion of modified diesel engine to NG engine can reduce indicated power $12.58 \%, 12.77 \%, 21.1 \%, 38.14 \%$, $46.84 \%$ and $54.92 \%$. It meant that the NG engine not applicable to run on high speed and very good power performance in medium speed. The combustion in high speed is produce lower power than the medium speed because the NG engine is developed in low compression ratio and thermodynamic energy. The effect of natural gas combustion of NG engine is lower in thermodynamic energy. The effect of lower thermodynamic energy is lower in indicated power.

Friction power of original diesel engine, modified diesel engine and port injection NG engine are shown in Fig. 8b. The simulation and experimental investigation results are not similar in 0.5 to $1.5 \%$. The simulation results are higher than the experimental results, it caused by the not excellently setting and reading data experiment and the assumption in simulation with not have losses. In the original and modified diesel engine, the highest friction power is negative $2.17 \mathrm{~kW}$ and $2.03 \mathrm{~kW}$ declared at $4000 \mathrm{rpm}$ engine speed. The friction power profile shows that from the minimum engine speed at $1500 \mathrm{rpm}$ to maximum engine speed on $4000 \mathrm{rpm}$, the friction power is increase if the engine speed is increased. In the multi point injection NG engine, the highest friction torque is negative $1.9 \mathrm{~kW}$ and declared on $4000 \mathrm{rpm}$ engine speed. The friction power profile shows that increasing engine speed from the minimum engine speed at $1500 \mathrm{rpm}$ to maximum engine speed at $4000 \mathrm{rpm}$ is increase the friction power. In both of the NG engine and diesel engine, the friction power is increase if the engine speed is increased.

The conversion diesel engine to NG engine can increase the friction power performance percentage. The increasing engine speed can be increase the friction power of NG engine compared to diesel engine. The percentage friction power of NG engine is higher than the diesel engine in every engine speed. In $1500 \mathrm{rpm}$, the friction power of NG engine is $15.02 \%$ and diesel engine is $15.21 \%$ from the indicated power. In $2000 \mathrm{rpm}$, the friction power of NG engine is $17.45 \%$ and diesel engine is $16.03 \%$ from the indicated power. In $2500 \mathrm{rpm}$, the friction power of NG engine is $20.57 \%$ and diesel engine is $17.29 \%$ from the indicated power. In $3000 \mathrm{rpm}$, the friction power of NG engine is $27.22 \%$ and diesel engine is $18.6 \%$ from the indicated power. In $3500 \mathrm{rpm}$, the friction power of NG engine is $36.4 \%$ and diesel engine is 

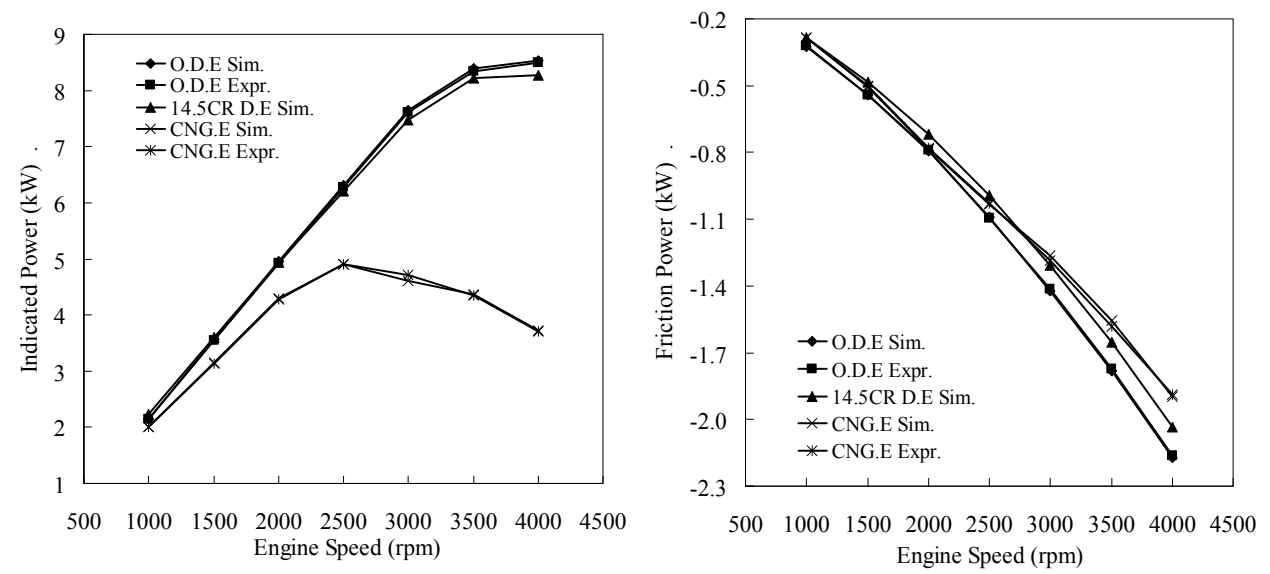

a) Indicated power of NG engine compared tob) Friction power of NG engine compared diesel engines

to diesel engines

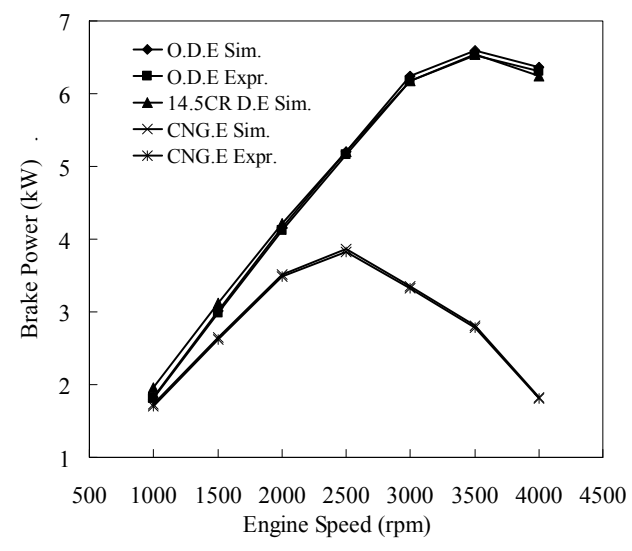

c) Brake power of NG engine compared

Fig. 8. Power performance of diesel engine convert to MPI NG engine.

$21.23 \%$ from the indicated power. In $4000 \mathrm{rpm}$, the friction torque of NG engine is $50.17 \%$ and diesel engine is $25.44 \%$ from the indicated power. The percentage deviation of friction power compared to the indicated power of NG engine is lower than diesel engine in low engine speed until $1500 \mathrm{rpm}$. If the engine is running in higher than $1500 \mathrm{rpm}$ engine speed, the NG engine friction power is higher than diesel engine. In these cases the increasing engine speed will be increase the friction power both of the engines and the NG engine give more friction power. It meant that the conversion of diesel engine to NG engine can be increase the friction power of engine. It is caused by the natural gas properties aspects, 
where in the natural gas as a fuel, the engine is less of the lubrication liquid compared to diesel fuel. Diesel fuel as a liquid fuel is have lubrication to reduce the friction.

Brake power performance of original diesel engine, modified diesel engine and port injection NG engine are shown in Fig. 8c. The brake power represents the power available at the flywheel, after accounting for all friction and attachment losses as well as the acceleration of the crank train inertia for brake torque. In the port injection NG engine, the highest brake power is $3.87 \mathrm{~kW}$ declared at $2500 \mathrm{rpm}$ engine speed. In the NG engine, from 1500 to $2500 \mathrm{rpm}$, the increasing engine speed is increase brake power. After $2500 \mathrm{rpm}$ engine speed, the increasing engine speed can be decrease the brake power. The simulation and experimental investigation results are not similar average in $1.0 \%$. The simulation results are higher than the experimental results, it caused by the not excellently setting and reading data experiment and the assumption in simulation with not have losses. In the original and modified diesel engine, the highest brake power is $6.6 \mathrm{~kW}$ and $6.54 \mathrm{~kW}$ declared at $3500 \mathrm{rpm}$ engine speed. In the diesel engines, the brake power performance profile shows that from the minimum engine speed at $1500 \mathrm{rpm}$ to $3500 \mathrm{rpm}$ as the point of the highest brake power, brake power performance is increase if the engine speed is increased until $3500 \mathrm{rpm}$ engine speed. After $3500 \mathrm{rpm}$ engine speed, the increasing engine speed can be decrease the brake power. The conversion of four stroke direct injection diesel engine to multi point injection NG engine can reduce the engine brake power performance. The maximum brake power of direct injection diesel engine convert to multi point injection NG engine is reduced $41.374 \%$. The increasing engine speed can be increase the deviation point or deviation percentage of the brake power of diesel engine compared to NG engine. So, the increasing engine speed can be increase the percentage deviation of brake power of the NG engine and diesel engines. If both of the engines are run on 1500 to $4000 \mathrm{rpm}$, the conversion of modified direct injection diesel engine to port injection NG engine has been reduced brake power $15.14 \%, 16.47 \%, 25.67 \%, 45.68 \%, 57.04 \%$ and $70.68 \%$. The increasing engine speed can be increase the percentage deviation of power performance of NG engine compared to diesel engine. The reduction of the brake power in the NG engine is caused by low of brake torque. The low brake torque is caused by the low density of natural gas, low energy of natural gas, low volumetric efficiency, low flame speed, low compression ratio and higher friction of NG as an alternative fuel.

The investigation results on indicated power, friction power and brake power of the diesel engine converted to NG engine are shown that the engine conversion development can be decrease engine power performance. Increasing of engine speed over medium speed can be decreasing engine power performance of NG engine.

\subsection{Fuel consumption of multi point injection Natural Gas engine}

The simulation and experimental investigation results of the fuel consumption investigation of the diesel engines and NG engine are focuses on the indicated specific fuel consumption and brake specific fuel consumption. The investigation results are shown in Fig. 9.

Indicated specific fuel consumption (ISFC) of original diesel engine, modified diesel engine and port injection NG engine are shown in Fig. 9a. The ISFC is the nominal total fuel were used the engine to product their indicated power output. The simulation results are higher 


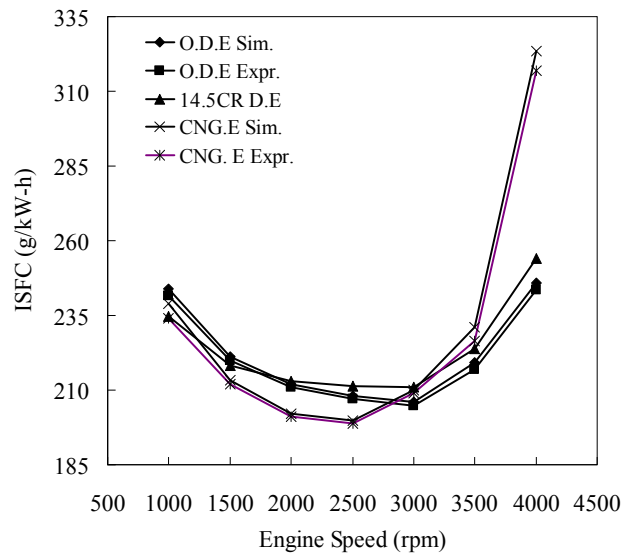

a) ISFC of NG engine

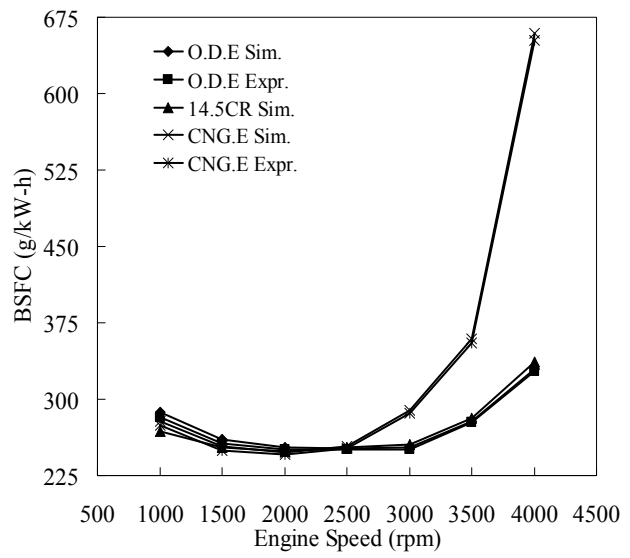

b) BSFC of NG engine

Fig. 9. Specific fuel consumption of diesel engine convert to MPI NG engine.

than the experimental results, it caused by the not excellently setting and reading data experiment and the assumption in simulation with not have losses. In the port injection NG engine, the fuel is entering to engine cylinder via intake port, the lowest ISFC is 199.593 $\mathrm{g} / \mathrm{kW}$-h declared on $2500 \mathrm{rpm}$ engine speed and the highest ISFC is $323.532 \mathrm{~g} / \mathrm{kW}-\mathrm{h}$

declared on $4000 \mathrm{rpm}$ engine speed. From the minimum engine speed to $2500 \mathrm{rpm}$ engine speed, the increasing engine speed can be decrease the ISFC. After 2500 to $4000 \mathrm{rpm}$, the increasing engine speed can be increase the ISFC. In the original and modified direct injection diesel engine, the fuel is injected directly to engine cylinder, the lowest ISFC are $205.93 \mathrm{~g} / \mathrm{kW}$-h and $210.98 \mathrm{~g} / \mathrm{kW}$-h declared on $3000 \mathrm{rpm}$ engine speed. Then, the highest ISFC are $245.981 \mathrm{~g} / \mathrm{kW}-\mathrm{h}$ and $254 \mathrm{~g} / \mathrm{kW}$-h declared on $4000 \mathrm{rpm}$ engine speed. The ISFC profile shows that from the minimum engine speed at $1500 \mathrm{rpm}$ to medium speed, the increasing engine speed is decrease the ISFC. From medium speed to maximum engine speed at $4000 \mathrm{rpm}$, the increasing engine speed is increase the ISFC. The conversion of diesel engine to NG engine can be reduce the ISFC in the low to medium engine speed, but in the medium engine speed to high speed can be increase the ISFC. The minimum ISFC of multi point injection NG engine is reduced $2.9 \%$ compared to direct injection diesel engine. The maximum ISFC of port injection NG engine has increase $31.53 \%$ compared to direct injection diesel engine. The increasing engine speed can be increase the ISFC of NG engine compared to both of diesel engines. It meant that the NG engine not applicable to run on high speed, but it is very good ISFC in medium speed. The combustion in high speed is not excellent, not completely and high in unburned fuel, so the engine is produce lower power than the medium speed because the NG engine is developed in low energy and low density. The effect of the lower energy, density and power is increase the ISFC to the higher.

Brake specific fuel consumption (BSFC) of original diesel engine, modified diesel engine and port injection NG engine are shown in Fig. 9b. The BSFC is the nominal total fuel were used 
in the engine to product their brake power output. The simulation results are higher than the experimental results, it caused by the not excellently setting and reading data experiment and the assumption in simulation with not have losses. In the original and modified diesel engine, the lowest BSFC is $252 \mathrm{~g} / \mathrm{kW}-\mathrm{h}$ and $249.18 \mathrm{~g} / \mathrm{kW}-\mathrm{h}$ declared in 2500 and $2000 \mathrm{rpm}$ engine speed. Then, the highest BSFC both of the diesel engines are 329.678 $\mathrm{g} / \mathrm{kW}-\mathrm{h}$ and $336.62 \mathrm{~g} / \mathrm{kW}-\mathrm{h}$ declared in $4000 \mathrm{rpm}$ engine speed. In the original diesel engine, the BSFC profile shows that from $1500 \mathrm{rpm}$ to $2500 \mathrm{rpm}$, the increasing engine speed can be decrease the BSFC. After $2500 \mathrm{rpm}$ engine speed, the increasing engine speed can be increase the BSFC. In the modified diesel engine, the BSFC profile shows that from $1500 \mathrm{rpm}$ to $2000 \mathrm{rpm}$, the increasing engine speed can be decrease the BSFC. But, after $2000 \mathrm{rpm}$ engine speed, the increasing engine speed can be increase the BSFC. In the port injection NG engine, the lowest BSFC is $247.23 \mathrm{~g} / \mathrm{kW}-\mathrm{h}$ declared in $2000 \mathrm{rpm}$ engine speed and the highest BSFC is $659 \mathrm{~g} / \mathrm{kW}$-h declared in $4000 \mathrm{rpm}$ engine speed. From 1500 to $2000 \mathrm{rpm}$ engine speed, the increasing engine speed of NG engine has been reduced the BSFC. After 2000 to $4000 \mathrm{rpm}$ engine speed, the increasing engine speed can be increase the BSFC extremely. Its means, that the conversion of direct injection diesel engine to multi point injection NG engine can reduce the BSFC in lowest to medium engine speed and increase the BSFC in medium to highest engine speed. The minimum BSFC of modified direct injection diesel engine convert to port injection NG engine is reduced $0.78 \%$. The maximum BSFC of modified direct injection diesel engine convert to port injection NG engine is increase $95.79 \%$. The increasing engine speed can be increase the deviation point or deviation percentage of the BSFC of diesel engine compared to NG engine. In the low to medium engine speed, the unburned fuel in NG engine combustion is decrease so the out put can be product the higher torque and power. From the medium to the highest engine speed, the combustion of NG engine is not excellently, so the fuel consumption is increase because the unburned fuel is increase in the medium to highest speed. The effect of the increasing unburned fuel is can be decrease the engine brake torque and brake power. The effect of lower brake torque and brake power is increase the BSFC.

\subsection{Mean effective pressure of multi point injection Natural Gas engine}

The IMEP result is shown in Fig. 10a. The simulation and experimental investigation results are not similar average in $1.5 \%$ for both of the engines. The simulation results are higher than the experimental results, it caused by the not excellently setting and reading data experiment and the assumption in simulation with not have losses. In the NG engine, the highest IMEP is 6.34952 bar declared on $2000 \mathrm{rpm}$ engine speed. From the minimum engine speed to $2000 \mathrm{rpm}$ engine speed, the increasing engine speed can be increase the IMEP. After $2000 \mathrm{rpm}$ to maximum engine speed, the increasing engine speed can be decrease the IMEP. In the original and modified diesel engine, the highest IMEP is 7.5242 bar and 7.34 bar declared on $3000 \mathrm{rpm}$ engine speed. The IMEP performance profile of diesel engines shows that from the minimum engine speed at 1500 to $3000 \mathrm{rpm}$ engine speed, the increasing engine speed can be increase the IMEP, but from $3000 \mathrm{rpm}$ to maximum engine speed at $4000 \mathrm{rpm}$, the increasing engine speed can be decrease the IMEP. Based on Fig.10a, the conversion diesel engine to NG engine can reduce the IMEP. The maximum IMEP of modified direct injection diesel engine convert to port injection NG engine has been reduced 


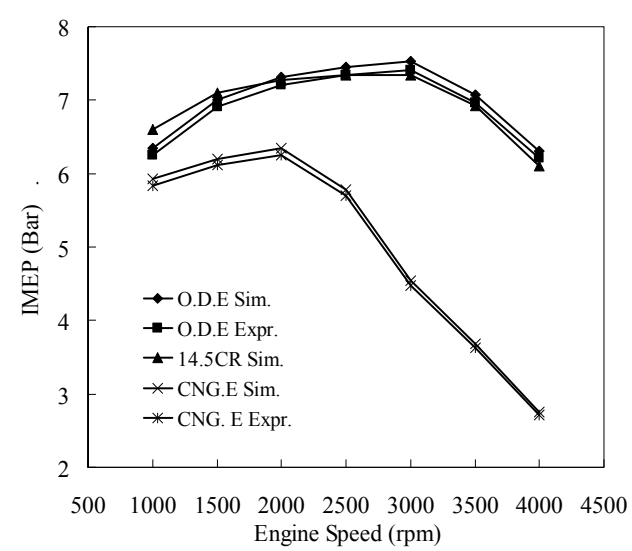

a) IMEP of NG engine

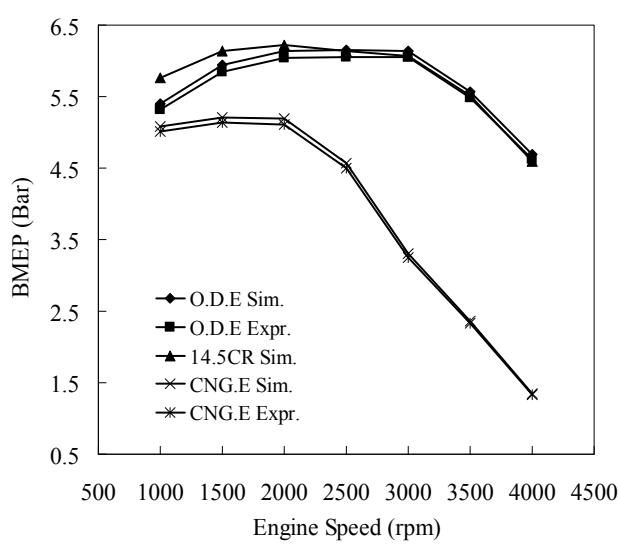

b) BMEP of NG engine

Fig. 10. Mean effective pressure of diesel engine convert to MPI NG engine.

$13.54 \%$. The increasing engine speed can be increase the deviation point or percentage deviation of the IMEP of NG engine compared to diesel engine. If the engine is run on 1500 to $4000 \mathrm{rpm}$, the conversion of modified diesel engine to port injection NG engine It meant that the NG engine not applicable to run on high speed and very good IMEP performance in low to medium speed. The combustion in high speed produces lower IMEP than the medium speed because the NG engine is developed in low energy. Effect of lower energy is causing the lower indicated torque. The lower indicated torque is can be reducing the lower IMEP.

Brake mean effective pressure (BMEP) performance of original diesel engine, modified diesel engine and port injection NG engine are shown in Fig. 10b. The BMEP is the external shaft work done per unit displacement. The simulation results are higher than the experimental results, it caused by the not excellently setting and reading data experiment and the assumption in simulation with not have losses. In the port injection NG engine, the highest BMEP is 5.21 bar declared on $1500 \mathrm{rpm}$ engine speed. From 1500 to $1500 \mathrm{rpm}$, the increasing engine speed is increase BMEP. After $1500 \mathrm{rpm}$ engine speed, the increasing engine speed can be decrease the BMEP. In the original and modified diesel engine, the highest BMEP are 6.148 bar and 6.22 bar declared at 2500 and $2000 \mathrm{rpm}$ engine speed. The BMEP performance profile of original and modified diesel engine shows that the BMEP performance is increase if the engine speed is increased until 2500 and $2000 \mathrm{rpm}$ engine speed. After 2500 and $2000 \mathrm{rpm}$ engine speed, the increasing engine speed can be decrease the BMEP. The conversion of four stroke direct injection diesel engine to multi point injection NG engine can be reducing the engine BMEP performance. The maximum BMEP of modified direct injection diesel engine convert to port injection NG engine is reduced $16.18 \%$. If the engines are run on 1500 to $4000 \mathrm{rpm}$, the conversion of diesel engine to port injection NG engine reduced BMEP 15.14\%, 16.48\%, 25.67\%, 45.68\%, 57\% and $70.68 \%$. 
The investigation results on mean effective pressure performance such as indicated and break mean effective pressure of direct injection diesel engine converted to port injection NG engine are shown that the engine conversion development can be decrease the engine power performance. The reduction of the mean effective pressure in the NG engine is caused by lower energy, density and higher friction of compressed natural gas as an alternative fuel for engines. The increasing of engine speed over the medium speed can be decrease the engine mean effective pressure performance of NG engine. The highest of engine mean effective pressure of NG engine is declared in medium engine speed and the lowest mean effective pressure is declared in highest engine speed. The increasing engine speed will be increase the percentage deviation of mean effective pressure performance of NG engine compared to diesel engine.

\section{Conclusion}

The original diesel engine cylinder pressure is higher than the modified diesel engine and $\mathrm{CNG}$ engine. It caused the compression ratio of NG engine is lower than the original diesel engine and the combustion energy output of diesel fuel has to produce the highest power than natural-gas fuel. Another that, the density of natural-gas fuel is lower than the diesel fuel. The increasing engine speed of the diesel engine has increase the maximum temperature in engine. Unfortunately, the increasing engine speed of NG engine has been decrease maximum temperature inin- engine. The decreasing engine speed of diesel engines has been decrease maximum temperature inin- engine. Decreasing engine speed of NG engine has increase maximum temperature in engine. Engine torque, power, mean effective pressure and efficiency performance of original direct injection diesel engine cylinder pressure is higher than the modified diesel engine and sequential port injection dedicated NG engine. It meant that the thermodynamics energies were resulted from the diesel fuel combustion is higher than the NG fuel. It caused by the hydrocarbon chain, density and energy of diesel fuel of the diesel engine is higher than the gas fuel of NG engine were ignited using to spark assistant. The fuel consumption of NG engine is higher than the diesel engine. Fuel consumption is increased because the unburned fuel is increased in the medium to the highest speed of NG engine. The effect of the increasing unburned fuel is can decrease the engine brake torque and brake power. The effect of lower brake torque and brake power increase the brake specific fuel consumption..

\section{References}

Aslam, M.U.; Masjuki, H.H.; Kalam, M.A.; Abdesselam, H.; Mahlia, T.M.I.; Amalina, M.A. (2006). An experimental investigation of CNG as an alternative fuel for a retrofitted gasoline vehicle. Fuel 85: 717-724.

Bakar, R. A.; Sera, M.A.; Mun, W.H. (2002). Towards The Implementation of CNG Engine: A Literature Review Approach To Problems And Solutions. Proc. of BSME-ASME International Conference on Thermal Engineering. December 31, 2001 - January 2, 2002. Dhaka. BSME-ASME. 2002. 
Brombacher, E.J. (1997). Flow Visualisation of Natural Gas Fuel Injection, MSc Thesis, University of Toronto.

Catania, A.E.; Misul, D.; Spessa, E.; Vassallo, A. (2004). Analysis of combustion parameters and their relation to operating variables and exhaust emissions in an upgraded multivalve bi-fuel CNG SI engine. SAE Paper. 2004-01-0983.

Chiu, J.P. (2004). Low Emissions Class 8 Heavy-Duty, On-Highway Natural Gas and Gasoline Engine. SAE Paper. 2004-01-2982.

Cho, H. M.; He, Bang-Quan (2007). Spark ignition natural gas engines - A review. Energy Conversion and Management 48: 608-618.

Czerwinski J.; Comte P.; Janach.W.; Zuber P. (1999). Sequential Multipoint Trans-ValveInjection for Natural Gas Engines. SAE Paper. 1999-01-0565.

Czerwinski, J.; Comte, P.; Zimmerli, Y. (2003). Investigations of the Gas Injection System on a HD-CNG-Engine. SAE Paper. 2003-01-0625.

Duan, S.Y. (1996). Using Natural Gas in Engines: Laboratory experience with the use of natural gas fuel in IC engines. IMechE Seminar Publication, 1996: 3946.

Durrel, Elizabeth.; Allan, Jeff.; Law, Donald.; Heath, John. (2000). Installation and Development of a Direct Injection System for a Bi-Fuel Gasoline and Compressed Natural Gas. Proceeding of ANGV Conference 2000. October 17 - 19, 2000. Yokohama: ANGV.

Evan, R.L.; Blaszczyk, J.; and Matys, P. (1996). An Experimental and Numerical Study of Combustion Chamber Design for Lean-Burn Natural Gas Engines. SAE Paper. 961672.

Ganesan, V. (1999). Internal Combustion Engines. N.Delhi: Tata McGraw-Hill.

Hollnagel, Carlos.; Borges, Luiz.H.; Muraro, Wilson. (1999). Combustion Development of the Mercedes-Benz MY1999 CNG-Engine M366LAG. SAE Technical Paper 1999-013519.

Hollnagel, C.; Neto, J. A. M.; Di Nardi, M. E.; Wunderlich, C.; Muraro, W. (2001). Application of the natural gas engines Mercedes-Benz in moving stage for the carnival 2001 in Salvador City. SAE Paper. 2001-01-3824.

Johansson, B. and Olsson, K. (1995). Combustion Chambers for Natural Gas SI Engines Part I: Fluid Flow and Combustion. SAE Paper. 950469.

Kato, K.; Igarashi, K.; Masuda, M.; Otsubo, K.; Yasuda, A.; Takeda, K.; Sato, T. (1999). Development of engine for natural gas vehicle. SAE Paper. 1999-01-0574. 1999.

Kawabata, Y and Mori, D. (2004). Combustion diagnostics and improvement of a prechamber lean-burn natural gas engine. SAE Paper. 2004-01-0979.

Klimstra, J. (1989). Carburetors for Gaseous Fuels - On Air-to-Fuel Ratio, Homogeneity and Flow Restriction. SAE Paper 892141.

Kowalewicz, Andrzej. (1984). Combustion System of High-Speed Piston I.C. Engines. Warszawa: Wydawnictwa Komunikacji i Lacznosci..

Kubesh, J.T.; Podnar, D.J.; Gugliemo, K.H. and McCaw, D. (1995). Development of an Electronically-Controlled Natural Gas-Fueled John Deere Power Tech 8.1L Engine. SAE Paper .951940. 
Kubesh, John. T.; Podnar, Daniel. J. (1998). Ultra Low Emissions and High Efficiency from On-Highway Natural Gas Engine. SAE Paper 981394.

Lino, Paolo.; Maione, Bruno.; Amorese, Claudio. (2008). Modelling and predictive control of a new injection system for compressed natural gas engines. Control Engineering Practice, 2008. 16 (10): 1216-1230.

Mbarawa, M.; Milton, B.E.; Casey, R.T. (2001). Experiments and modelling of natural gas combustion ignited by a pilot diesel fuel spray. Int. J. Therm. Sci. 40: 927936.

Oullette, P.; Mtui, P.L.; Hill, P.G. (1998). Numerical Simulation of Directly Injected Natural Gas and Pilot Diesel Fuel in a Two Stroke Compression Ignition Engine. State of Alternative Fuel Technologies. SAE Paper 981400.

Ouellette, Patric. (2000). High Pressure Direct Injection (HPDI) of Natural Gas in Diesel Engines. Proceeding ANGVA 2000 Conference. Yokohama.

Pischinger, S.; Umierski, M.; Hüchtebrock, B (2003). New CNG concepts for passenger cars: High torque engines with superior fuel consumption. SAE Paper. 2003-012264.

Poulton, M.L. (1994). Alternative Fuels for Road Vehicles, Computational Mechanics Publication, London.

Ren, W and Sayar, H. (2001). Influence of nozzle geometry on spray atomization and shape for port fuel injector. SAE Paper. 2001-01-0608.

Sera, M.A.; Bakar, R.A.; Leong, S.K. (2003) CNG engine performance improvement strategy through advanced intake system. SAE Paper. 2003-01-1937.

Shashikantha.; Parikh, P.P. (1999). Spark ignition producer gas engine and dedicated compressed natural gas engine-Technology development and experimental performance optimization. SAE Paper.1999-01-3515.

Shiga, S.; Ozone, S.; Machacon, H. T. C.; Karasawa, T. (2002). A Study of the Combustion and Emission Characteristics of Compressed-Natural-Gas Direct-Injection Stratified Combustion Using a Rapid-Compression-Machine, Combustion and Flame 129:1-10.

Suga, T.; Muraishi, T.; Brachmann, T.; Yatabe, F. (2000). Potential of a natural gas vehicle as EEV. SAE Paper. 2000-01-1863.

Tilagone, R.; Monnier, G.; Chaouche, A.; Baguelin, Y. and Chauveron D.S. (1996). Development of a High Efficiency, low Emission SI-CNG Bus Engine. SAE Paper. 961080.

Vermiglio. E; Jenskins, T.; Kleliszewski, M.; Lapetz, J.; Povinger, B.; Willey, R.; Herber, J.; Sahutske, K.; Blue, M, and Clark, R. (1997). Ford's SULEV Dedicated Natural Gas Trucks. SAE Paper. 971662.

Wang, D. E and Watson, H. C. (2000). Direct injection compressed natural gas combustion and visualization. SAE Paper 2000-01-1838.

Wayne, W. S.; Clark, N. N.; Atkinson, C. M. (1998). A parametric study of knock control strategies for a bi-fuel engine. SAE Paper. 980895.

Zastavniouk, Oleg. (1997). Study of Mixing Phenomena in a Dual Fuel Diesel Engine Air Intake Manifold. MSc Thesis. University of Alberta. 
Zhao, F.; Lai, M.; Harrington, D.L. (1995). The Spray Characteristics of Automotive Port Fuel Injection - A Critical Review. SAE Paper. 950506. 


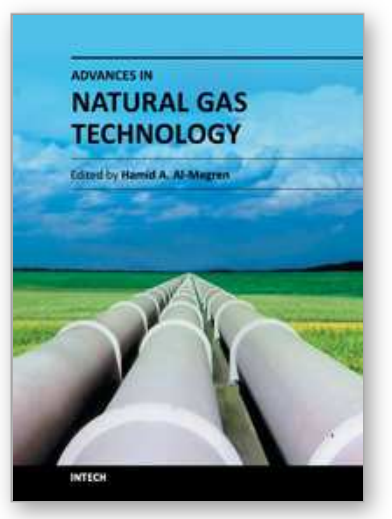

\author{
Advances in Natural Gas Technology \\ Edited by Dr. Hamid Al-Megren
}

ISBN 978-953-51-0507-7

Hard cover, 542 pages

Publisher InTech

Published online 11, April, 2012

Published in print edition April, 2012

Natural gas is a vital component of the world's supply of energy and an important source of many bulk chemicals and speciality chemicals. It is one of the cleanest, safest, and most useful of all energy sources, and helps to meet the world's rising demand for cleaner energy into the future. However, exploring, producing and bringing gas to the user or converting gas into desired chemicals is a systematical engineering project, and every step requires thorough understanding of gas and the surrounding environment. Any advances in the process link could make a step change in gas industry. There have been increasing efforts in gas industry in recent years. With state-of-the-art contributions by leading experts in the field, this book addressed the technology advances in natural gas industry.

\title{
How to reference
}

In order to correctly reference this scholarly work, feel free to copy and paste the following:

Rosli Abu Bakar, K. Kadirgama, M.M. Rahman, K.V. Sharma and Semin (2012). Application of Natural Gas for Internal Combustion Engines, Advances in Natural Gas Technology, Dr. Hamid Al-Megren (Ed.), ISBN: 978953-51-0507-7, InTech, Available from: http://www.intechopen.com/books/advances-in-natural-gastechnology/application-of-natural-gas-for-internal-combustion-engines

\section{INTECH}

open science | open minds

\section{InTech Europe}

University Campus STeP Ri

Slavka Krautzeka 83/A

51000 Rijeka, Croatia

Phone: +385 (51) 770447

Fax: +385 (51) 686166

www.intechopen.com

\author{
InTech China \\ Unit 405, Office Block, Hotel Equatorial Shanghai \\ No.65, Yan An Road (West), Shanghai, 200040, China \\ 中国上海市延安西路65号上海国际贵都大饭店办公楼405单元 \\ Phone: $+86-21-62489820$ \\ Fax: +86-21-62489821
}


(C) 2012 The Author(s). Licensee IntechOpen. This is an open access article distributed under the terms of the Creative Commons Attribution 3.0 License, which permits unrestricted use, distribution, and reproduction in any medium, provided the original work is properly cited. 